\title{
Population structure of Paralonchurus brasiliensis (Steindachner, 1875) (Perciformes: Sciaenidae) in the coast of Sergipe, northeastern Brazil
}

\author{
Estrutura populacional de Paralonchurus brasiliensis (Steindachner, 1875) (Perciformes: \\ Sciaenidae) na costa de Sergipe, nordeste do Brasil \\ K. M. F. Freire ${ }^{*}$, J. V. Diniz ${ }^{1}$, T. M. R. R. Barreto ${ }^{2}$, M. F. G. Brito ${ }^{3}$, I. F. L. \\ Canuto $^{1}$, T. M. Silva ${ }^{1}$ \\ ${ }^{1}$ Laboratório de Ecologia Pesqueira, Departamento de Engenharia de Pesca e Aquicultura, Universidade Federal de \\ Sergipe, 49100-000, São Cristóvão-Sergipe, Brazil \\ ${ }^{2}$ Laboratório de Ciências da Pesca, Instituto do Mar, Universidade Federal de São Paulo, 11015-020, Santos-São \\ Paulo, Brazil \\ ${ }^{3}$ Laboratório de Ictiologia, Departamento de Biologia, Universidade Federal de Sergipe, 49100-000, São Cristóvão- \\ Sergipe, Brazil
}

*kmffreire2018@gmail.com

(Recebido em 28 de maio de 2020; aceito em 13 de novembro de 2020)

\begin{abstract}
Paralonchurus brasiliensis is one of the most common fish species found in the bycatch of shrimp trawling in Sergipe. We analyzed its population structure through four sampling programs, two using hired shrimp trawlers (2013-2014 and 2017-2018) and two from the commercial shrimp fleet (2015-2016 and 2018-2019). The codend mesh size varied among programs $(18,20$, and $21 \mathrm{~mm})$. All specimens of $P$. brasiliensis were identified and had their standard and total lengths (SL and TL; $\mathrm{cm}$ ) and their total weight (TW; g) measured. A total of 1509 specimens were collected measuring 4.7-22.9 cm TL and 0.4-114.8 g. About $67 \%$ of all specimens were below the length at first maturity $(14.7 \mathrm{~cm})$. The length-length and weight-length relationships estimated were $\mathrm{TL}=1.141+1.176 \times \mathrm{SL}$ and $\mathrm{TW}=0.00270 \times \mathrm{TL}^{3.391}$, respectively. The recruitment probably occurs in September-October and May. This species appeared to be more abundant at $15 \mathrm{~m}$, and larger individuals were found at $5 \mathrm{~m}$. Although $P$. brasiliensis is frequently caught in shrimp fisheries, it is not reported in catch statistics. Here, for the first time, we have documented its presence in Aracaju's market under the categories 'miunça' and 'pescadinha' (97\% adults), with the largest specimens landed and commercialized as 'pescadinha' together with other species. Smaller individuals are probably discarded by commercial fishers. The low selectivity of the fishing gear used leads to the capture of many juveniles, which may impact the population dynamics of this species as well as other species found in the same fishing ground. Keywords: banded croaker, sciaenids, bycatch
\end{abstract}

Paralonchurus brasiliensis é uma das espécies de peixes mais comuns na fauna acompanhante do arrasto de camarão em Sergipe. Nós analisamos sua estrutura populacional através de quatro programas amostrais, dois usando arrasteiros de camarão contratados (2013-2014 e 2017-2018) e dois da frota camaroneira comercial (2015-2016 e 2018-2019). O tamanho da malha no saco da rede variou entre os programas (18, 20 e $21 \mathrm{~mm}$ ). Todos os espécimes de $P$. brasiliensis presentes nas amostras foram identificados e tiveram seus comprimentos padrão e total $(\mathrm{CP}$ e CT; $\mathrm{cm}$ ) e seu peso total (PT; g) medidos. Um total de 1509 espécimes foi coletado medindo $4.7-22.9 \mathrm{~cm}$ CT e $0.4-114.8 \mathrm{~g}$. Cerca de $67 \%$ dos espécimes estavam abaixo do tamanho de primeira maturação $(14.7 \mathrm{~cm})$. As relações comprimento-comprimento e peso-comprimento estimadas foram $\mathrm{CT}=1.141+1.176 \times \mathrm{CP}$ e $\mathrm{PT}=0.00270 \times \mathrm{CT}^{3.391}$, respectivamente. $\mathrm{O}$ recrutamento provavelmente ocorre em setembro-outubro e maio. Esta espécie pareceu ser mais abundante em $15 \mathrm{~m}$ e os maiores indivíduos foram encontrados em $5 \mathrm{~m}$. Embora $P$. brasiliensis seja frequentemente capturada na pesca do camarão, não é registrada na estatística de captura. Nós documentamos aqui, pela primeira vez, sua presença no mercado de Aracaju nas categorias 'miunça' e 'pescadinha' (97\% adultos), com os maiores espécimes desembarcados e comercializados como 'pescadinha' junto com outras espécies. Indivíduos menores são provavelmente descartados pelos pescadores comerciais. A reduzida seletividade da arte de pesca utilizada leva à captura de muitos juvenis, o que pode impactar a dinâmica populacional dessa espécie, assim como de outras espécies encontradas na mesma área de pesca. 


\section{INTRODUCTION}

Shrimps are one of the main commodities currently available in the fishery market. Their total catch is usually small in relation to other groups, but their total value is high and ranked second in the world trade in 2016 [1]. In Brazil, shrimp fisheries were responsible for about $7 \%$ of the total catch of marine fisheries in 2011 [2] and their importance is even higher if the shrimp market value is considered. In the state of Sergipe, shrimp catches occupy the top position in production, reaching about $1292 \mathrm{t}$ and $1727 \mathrm{t}$ in 2013 and 2014, respectively [3, 4]. There is an Executive Order issued by the Fisheries Management Authority (Instrução Normativa MMA No14/2004) currently in place that establishes closed seasons for the shrimp fisheries in Sergipe state [5], but a recent study has shown the need to readjust these closed seasons to protect shrimp stocks [6].

Despite the high economic importance of shrimp fisheries, there are impacts on benthic habitats caused by capturing several non-target species referred to as bycatch, which includes juveniles of many fish species of commercial interest, that are often discarded into the sea immediately after being caught [7]. These negative impacts are exacerbated when trawling occurs in estuarine and coastal zones, as these areas represent nursery grounds for many species including those of commercial interest [8]. The low selectivity of fishing gears used in shrimp fisheries puts the local biodiversity at risk [9].

The family Sciaenidae is one of the fish families that is most affected by shrimp trawling in northeastern Brazil [10-12]. In Sergipe state, sciaenids also comprise the bulk of bycatch, representing $35 \%$ of the total fish bycatch by weight [13]. This family includes approximately 290 species [14], from which 37 species inhabit coastal regions along the Brazilian coast [15]. Paralonchurus brasiliensis (Steindachner, 1875), known as 'Maria Luíza' or 'coró', is one of the medium size sciaenids (commonly reaching $25 \mathrm{~cm}$, with a maximum size of $30 \mathrm{~cm}$ ) usually caught in shrimp fisheries, ranking fourth among the eighteen sciaenids reported in the bycatch of shrimp fisheries along the coast of Sergipe state [13]. This species occurs from Panama to southern Brazil and usually inhabits muddy or sandy bottoms of estuarine and coastal habitats [15-17]. Its diet is composed of marine invertebrates (e.g., worms and other benthic invertebrates) captured on the seabed [18]. Paralonchurus brasiliensis can reproduce all year round, however reproductive peaks are observed during the austral spring (October) and autumn (May) in Santa Catarina state [19].

Although P. brasiliensis is known to comprise part of the shrimp bycatch [13, 20], catch statistics available for Sergipe state in 2010-2014 do not include this species recorded either individually or associated with other sciaenids reported under a different common name [3, 4, 21-23]. Alcântara (2006) [24] recorded its occurrence in the estuary of the Sergipe River in 1980-1982 and 2004. With the exception of data on length at first maturity and reproduction period available for the state of Pernambuco [11], the entire northeastern region lacks information on natural history parameters for $P$. brasiliensis. Thus, the main objective of this study was to analyze all available data of $P$. brasiliensis from studies conducted along the coast of the state of Sergipe in order to understand its local population structure and to reveal the occurrence of this species in the local market, despite its absence from official catch statistical.

\section{MATERIALS AND METHODS}

The specimens of $P$. brasiliensis used in this study were derived from four sampling programs of shrimp fisheries carried out along the coast of Sergipe state (Figure 1) during different periods from 2013 to 2019. Details of each program are presented in Table 1. In all sampling programs, many different fish species were caught, but only data from $P$. brasiliensis were selected to be analyzed in this study. No sample was obtained during the closed shrimp season, with corresponds to April 1st until May 15th and December 1st to January 15th [5], except for the sampling program (1) (IBAMA/SISBIO Proc\# n. 02070.001067/2013-96). Sample collection for program (3) was obtained by license CEUA/UNISANTA N.03/2018. 


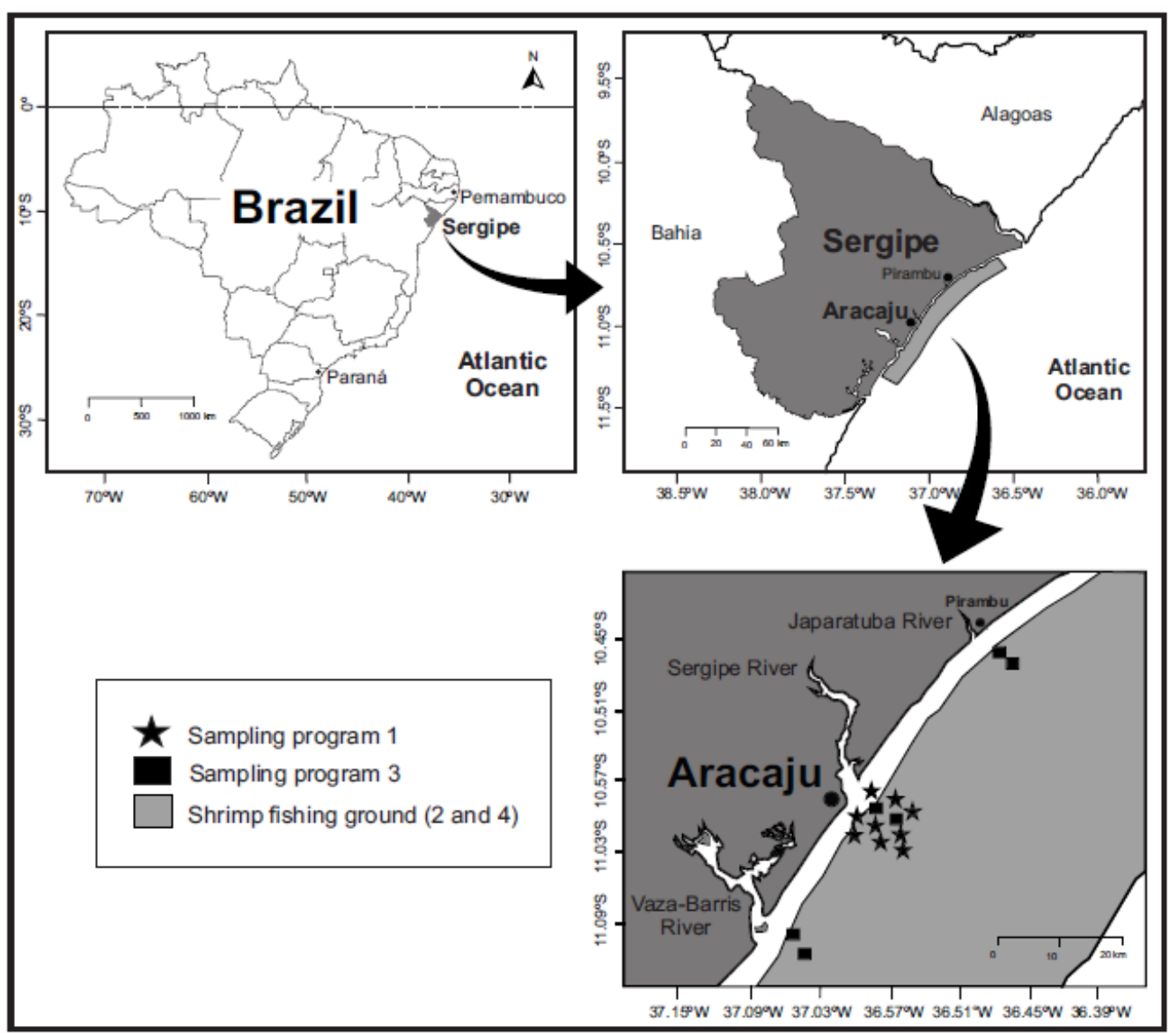

Figure 1: Map of Brazil indicating all states mentioned throughout this study. Sampling area in programs 2 and 4 of the shrimp commercial fleet (top right) and sampling points for two hired shrimp trawlers in sampling programs 1 and 3 (bottom) are also presented.

Samples from program (1) were taken to the Laboratório de Ictiologia and samples from programs (2) and (4) to the Laboratório de Ecologia Pesqueira, both at the Universidade Federal de Sergipe in São Cristóvão - Sergipe. Finally, samples from program (3) were taken to the Acervo Zoológico da Universidade Santa Cecília in Santos - São Paulo. All specimens of P. brasiliensis were identified $[17,18]$, separated and their standard length $(\mathrm{SL}, 0.1 \mathrm{~cm})$, total length $(\mathrm{TL}, 0.1 \mathrm{~cm})$, and total weight (TW, $0.1 \mathrm{~g}$ ) recorded. Specimens of P. brasiliensis are deposited in the Coleção Científica Regional de Peixes da Costa da Mata Atlântica of the Acervo Zoológico da Universidade Santa Cecília (AZUSC6011 and AZUSC6204).

Frequency distributions for total length were prepared for all specimens in each sampling program to better understand the relation between what was landed and what was most likely discarded. Additionally, length distributions per month were prepared in order to identify the recruitment period for $P$. brasiliensis in Sergipe state. Total length was compared among isobaths $(5,15$, and $30 \mathrm{~m})$ for sampling program (1) using a robust one-way analysis of variance (ANOVA) due to non-normality and heteroscedasticity in the data [25]. A post hoc test on trimmed means was applied using the lincon function available in $\mathrm{R}$ software - version 3.6.3. [26]. For sampling program (3), a linear regression was fitted to length data and local depth $(\mathrm{m})$ and its significance tested using an ANOVA for regression. A relationship between the total length and standard length was estimated for all sampling programs together to allow for comparison with other studies where different length measurements were used $(T L=a+b \times S L)$. 
Table 1: Description of sampling programs (1) to (4), which were conducted in the coast of Sergipe from 2013 to 2019 using shrimp boats. All specimens of Paralonchurus brasiliensis available in samples from these four sampling programs were separated and analyzed in this study. 'Complete' means shrimp plus bycatch.

\begin{tabular}{|c|c|c|c|c|c|c|}
\hline $\begin{array}{l}\text { Sampling } \\
\text { program }\end{array}$ & Period & Boat & $\begin{array}{c}\text { Gear } \\
\text { (mesh size } \\
\text { in cod end) } \\
\end{array}$ & Depth & $\begin{array}{l}\text { Total number } \\
\text { of samples }\end{array}$ & $\begin{array}{l}\text { Sample } \\
\text { features }\end{array}$ \\
\hline 1 & $\begin{array}{l}\text { September } 2013- \\
\text { August } 2014 \\
\text { (monthly, including } \\
\text { closed seasons) }\end{array}$ & Hired shrimp boat & $\begin{array}{l}\text { Double net } \\
(18 \mathrm{~mm})\end{array}$ & 5,15, and $30 \mathrm{~m}$ & $\begin{array}{l}108(12 \text { months } \times 3 \\
\text { sampling points } \times 3 \\
\text { isobaths } \times 1 \text { boat })\end{array}$ & $\begin{array}{l}\text { Shrimp and by-catch } \\
\text { (complete) }\end{array}$ \\
\hline 2 & $\begin{array}{l}\text { May } 2015 \text { - May } 2016 \\
\text { (monthly, excluding } \\
\text { closed seasons) }\end{array}$ & $\begin{array}{l}\text { Commercial shrimp boats } \\
\text { (Pirambu - Sergipe) }\end{array}$ & $\begin{array}{l}\text { Double net } \\
(21 \mathrm{~mm})\end{array}$ & Not provided & 48 (12 months $\times 4$ boats $)$ & $\begin{array}{l}\text { Shrimp and by-catch } \\
\text { (complete; commercial } \\
\text { fishers provided } 6 \mathrm{~kg} \\
\text { samples from each boat) } \\
\text { From data also used in } \\
\text { Barreto et al. [13] }\end{array}$ \\
\hline 3 & $\begin{array}{l}\text { October 2017, } \\
\text { February 2018, May } \\
\text { 2018, and July } 2018 \\
\text { (excluding closed } \\
\text { seasons) }\end{array}$ & Hired shrimp boat & $\begin{array}{l}\text { Double net } \\
(20 \mathrm{~mm})\end{array}$ & $\begin{array}{l}\text { Shallow (variable) } \\
\text { Deep (variable) }\end{array}$ & $\begin{array}{l}24 \text { ( } 4 \text { months } \times 3 \text { sampling } \\
\text { points } \times 2 \text { depth zones })\end{array}$ & $\begin{array}{l}\text { Shrimp and by-catch } \\
\text { (complete) }\end{array}$ \\
\hline 4 & $\begin{array}{l}\text { August } 2018 \text { - July } \\
2019 \text { (monthly, } \\
\text { excluding closed } \\
\text { seasons) }\end{array}$ & $\begin{array}{l}\text { Commercial shrimp boats } \\
\text { (Aracaju - Sergipe) }\end{array}$ & $\begin{array}{l}\text { Double net } \\
(21 \mathrm{~mm})\end{array}$ & Not provided & $\begin{array}{l}20(10 \text { months } \times 2 \\
\text { categories } \times 1 \text { boat })\end{array}$ & $\begin{array}{l}\text { Samples obtained from } \\
\text { fishes landed under } 2 \\
\text { categories: 'miunça' }(3 \mathrm{~kg}) \\
\text { and 'pescadinha' }(3 \mathrm{~kg})\end{array}$ \\
\hline
\end{tabular}


A weight-length relationship (WLR) was estimated for all samples grouped using a power model $\left(\mathrm{TW}=\mathrm{a} \times \mathrm{TL}^{\mathrm{b}}\right)$. Monthly WLRs for each sampling program (1-4) were also estimated looking for seasonal changes. For the sampling program (3), we estimated WLRs per month using the same data as those used by Barreto et al. (2018) [13] to estimate a single WLR for the entire year. For the detection of outliers, a Bonferroni Outlier Test was used [27]. All tests were performed using the R software - version 3.6.3. using a significance level of 5\% [26].

\section{RESULTS AND DISCUSSION}

A total of 1509 specimens of $P$. brasiliensis were caught during the four sampling programs: 755 in the sampling program (1), 413 in (2), 208 in (3), and 133 in (4). The smallest individual was $4.7 \mathrm{~cm}$ long (TL) and the largest, $22.9 \mathrm{~cm}$ TL. The total individual weight ranged from 0.4 to 114.8 g. Around $67 \%$ of all sampled specimens were below the length at first maturity of $14.7 \mathrm{~cm} \mathrm{TL}$, as estimated for P. brasiliensis off the coast of Pernambuco state [11]: 66.5\% in the sampling program (1) from a hired boat; $85.5 \%$ in the sampling program (2) from complete samples obtained from commercial boats before discarding; $71.5 \%$ in the sampling program (3) from a hired boat; and 3\% from categories 'miunça' and 'pescadinha' in the sampling program (4) from landed catch of commercial trawlers (Figure 2a-e). These results confirm the low selectivity of shrimp trawling, with a high percentage of juveniles being caught, resulting in substantial pressure on the small size classes of this bottom dwelling species. One should note that the total length for P. brasiliensis from 'miunça' is smaller than from 'pescadinha' and there was no specimen smaller than the length at first maturity in 'pescadinha' (Figure 2d-e). Paralonchurus brasiliensis is not individually recorded in the catch statistics of Sergipe state [3, 4, 21-23], but do occur within the categories 'miunça' and 'pescadinha', as we were able to demonstrate here. Given that within these categories most of the individuals of $P$. brasiliensis are above length at first maturity, juveniles that occur in the area are probably discarded into the sea. In the sampling programs (1), where a codend mesh size of $18 \mathrm{~mm}$ was used, the proportion in total weight of specimens smaller than $14.4 \mathrm{~cm}$ TL, which was the smallest size landed in the categories 'miunça' and 'pescadinha', was $35 \%$. For the sampling program (3), with a codend mesh size of $20 \mathrm{~mm}$, this proportion decreased to $31 \%$.

A closer analysis of length by month from the different sampling programs indicated new recruits (6 cm TL) are caught mainly in January, May and September-October (Figure 3), and May, July and October (Figure 4). Samples from programs (2) and (4) were not analyzed here as they originated from fishing trips lasting for up to 15 days and thus could include two different months in the same sample. It seems that May and October are recruitment periods for juveniles that may have been spawning 7-8 months before, if we consider the growth curves available for $P$. brasiliensis [16, 28], which corresponds to February-March and September-October. However, Silva Júnior et al. (2015) [11] were not able to define the reproduction period for this species at lower latitude, along the coast of Pernambuco state $\left(8.6^{\circ} \mathrm{S}\right)$, although spawned females were found in December-January. Spawned females were also found in the summer along the coast of Paraná state $\left(25.8^{\circ} \mathrm{S}\right)$, with an increasing number of mature females ready to spawn in the spring [29]. It is important that studies on the reproduction and growth of this species are carried out in Sergipe state to better understand the local population dynamics of this species. The relationship between total length and standard length estimated for $P$. brasiliensis in Sergipe state was TL $=1.141+1.176 \times \mathrm{SL}$ $\left(\mathrm{n}=1465 ; \mathrm{r}^{2}=0.976\right)$ and it was statistically significant $\left(\mathrm{F}=6.0 \times 10^{4} ; \mathrm{p}<0.0001\right)$. This relationship described in the present study is important to allow for comparisons with other research investigations, such as that from Santos Costa and collaborators (2013) [28], where SL was used. 

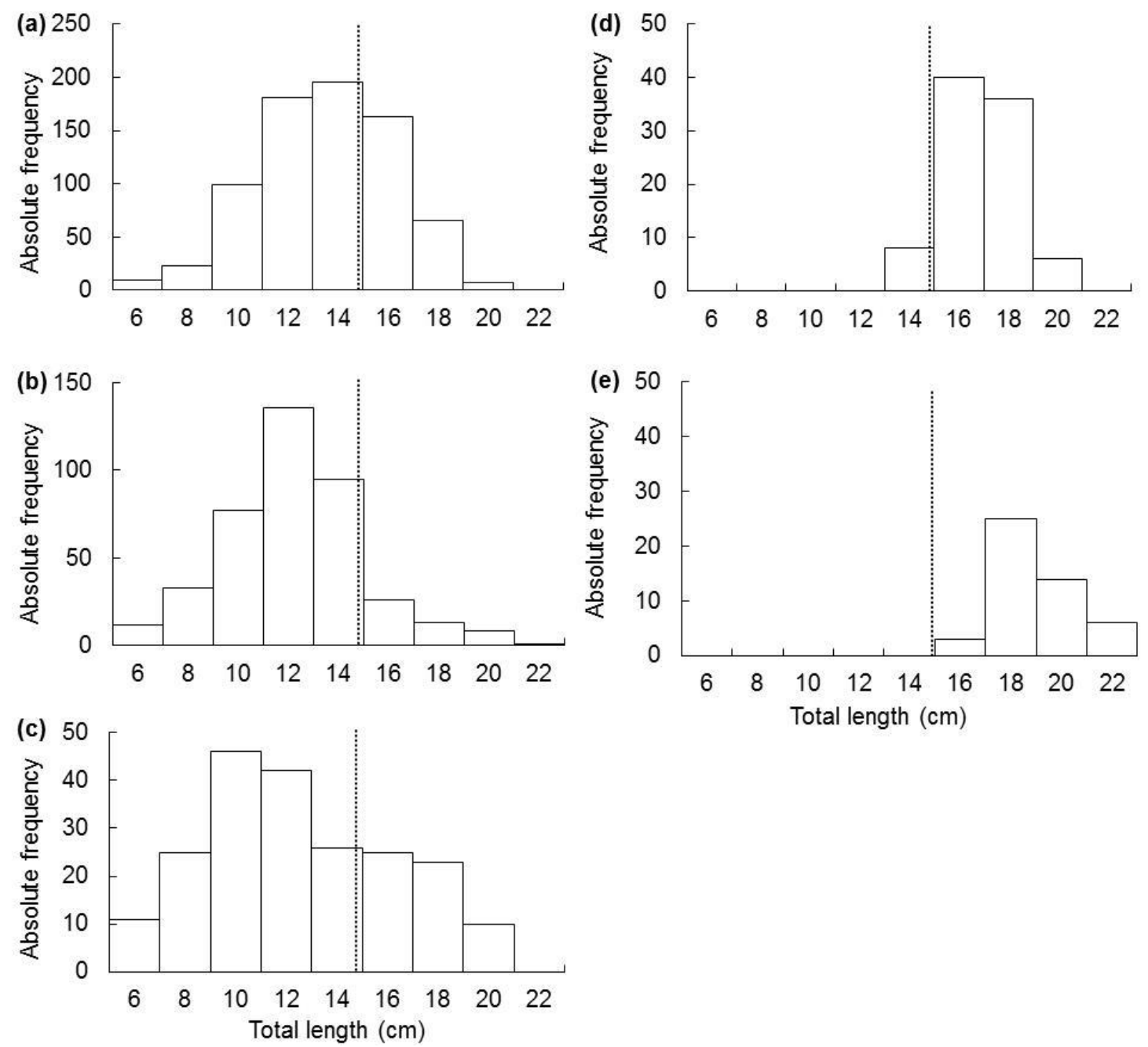

Figure 2: Frequency distribution of total length $(\mathrm{cm})$ for Paralonchurus brasiliensis in the coast of Sergipe: (a) Sampling program 1: 2013-2014, hired boat, codend mesh size =18 mm; (b) Sampling program 2: 2015-2016, complete sample from commercial boat, codend mesh size $=21 \mathrm{~mm}$; (c) Sampling program 3 :

2017-2018, hired boat, codend mesh size=20 mm; (d) and (e) Sampling program 4: 2018-2019, commercial boat, codend mesh size $=20 \mathrm{~mm}$ (samples from 'miunça' and 'pescadinha', respectively). The dotted vertical lines indicate the length at first maturity $(14.7 \mathrm{~cm} \mathrm{TL;} \mathrm{[11]).}$ 

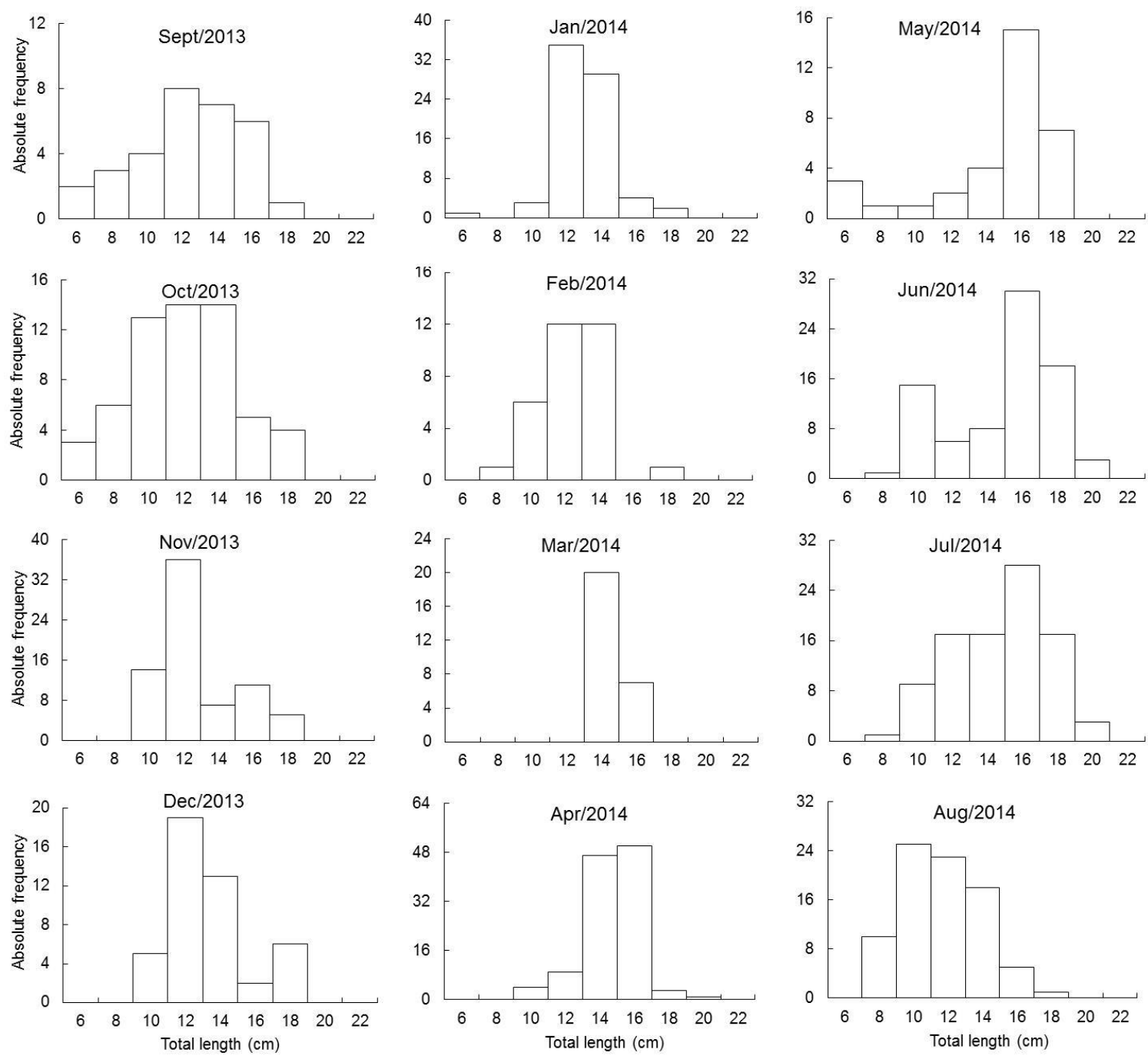

Figure 3: Monthly frequency distribution of total length $(\mathrm{cm})$ for Paralonchurus brasiliensis in the coast of Sergipe caught by a hired shrimp trawler (Sampling program 1, 2013-2014, codend mesh size $=18 \mathrm{~mm}$ ).
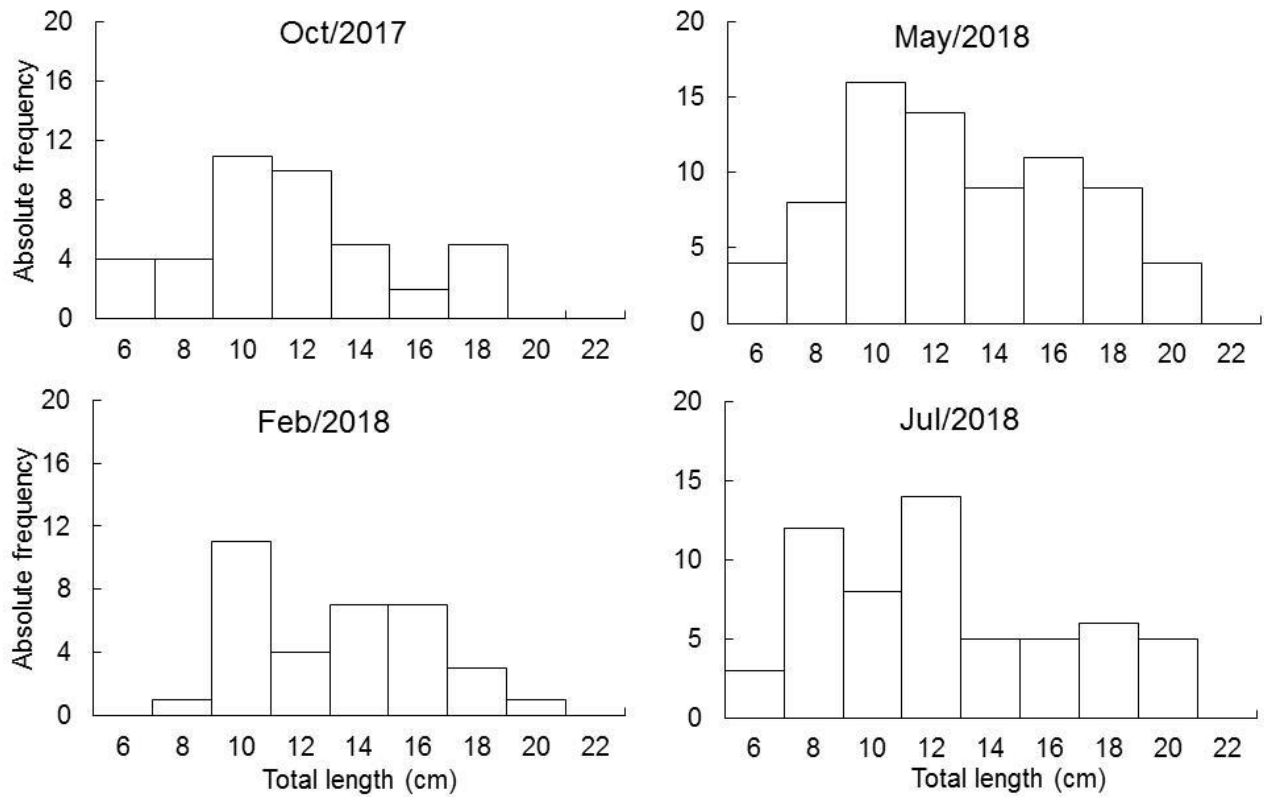

Figure 4: Monthly frequency distribution of total length ( $\mathrm{cm}$ ) for Paralonchurus brasiliensis in the coast of Sergipe caught by a hired shrimp trawler (2017-2018, sampling program 3, codend mesh size $=20 \mathrm{~mm}$ ). 
Some species exhibit spatial and temporal distribution pattern in their life cycle, which may vary according to the availability of resources, habitat quality, seasons, behavior and sex [30, 31]. In the present study, $P$. brasiliensis from different sizes were sampled in all depth strata in the sampling program (1) (2013-2014) (Figure 5a): 6.2-20.7 $\mathrm{cm}$ at $5 \mathrm{~m}$ (minimum-maximum), 5.2-20.6 cm at 15 $\mathrm{m}$, and $4.7-19.4 \mathrm{~cm}$ at $30 \mathrm{~m}$. The smallest individuals were found at 15 and $30 \mathrm{~m}$ (4.7-5.7 TL) during the months of September-October and May, which indicate the recruitment period. Results from the robust ANOVA indicated that depth had a significant effect on total length of $P$. brasiliensis in the region with a medium explanatory measure of effect size $(\mathrm{F}=17.845 ; \mathrm{p}<0.001)$. The post-hoc test indicated differences of total length between $5 \mathrm{~m}$ and $15 \mathrm{~m}(\widehat{\Psi}=1.308 ; \mathrm{p}<0.001)$, and between $5 \mathrm{~m}$ and $30 \mathrm{~m}(\widehat{\Psi}=0.995 ; \mathrm{p}=0.021)$, but not between $15 \mathrm{~m}$ and $30 \mathrm{~m}(\widehat{\Psi}=-0.31297$; $\mathrm{p}=0.404)$. Thus, the largest individuals were found at $5 \mathrm{~m}$ in this region. Data from sampling program (3) (2017-2018) were also able to show a slight decrease in size with increasing depth (Figure 5b; $F=36.204 ; \mathrm{p}<0.001$ ). However, the depth range of the sampling program (3) was too narrow (11-19 $\mathrm{m})$ and the relationship between length and depth not strong enough to support the existence of a clear spatial segregation in this area. One possible reason for this absence of spatial segregation is the narrow continental shelf with gradual slope and suitable substrate to forage in all extension [32], allowing for the presence of many ontogenetic stages in this area. Robert, MichelsSouza and Chaves (2007) [29] found specimens $2.2-23.7 \mathrm{~cm}$ at $10 \mathrm{~m}$ and only 1 individual out of 21 was smaller than $16.5 \mathrm{~m}$ at $15 \mathrm{~m}$ along the coast of Paraná state, where a codend mesh size of $25 \mathrm{~mm}$ was used. Here, $88.5 \%$ of the specimens found at $15 \mathrm{~m}$ were smaller than $16.5 \mathrm{~cm}$ where a mesh size of $18 \mathrm{~mm}$ was used in the sampling program (1) (Figure 5a).
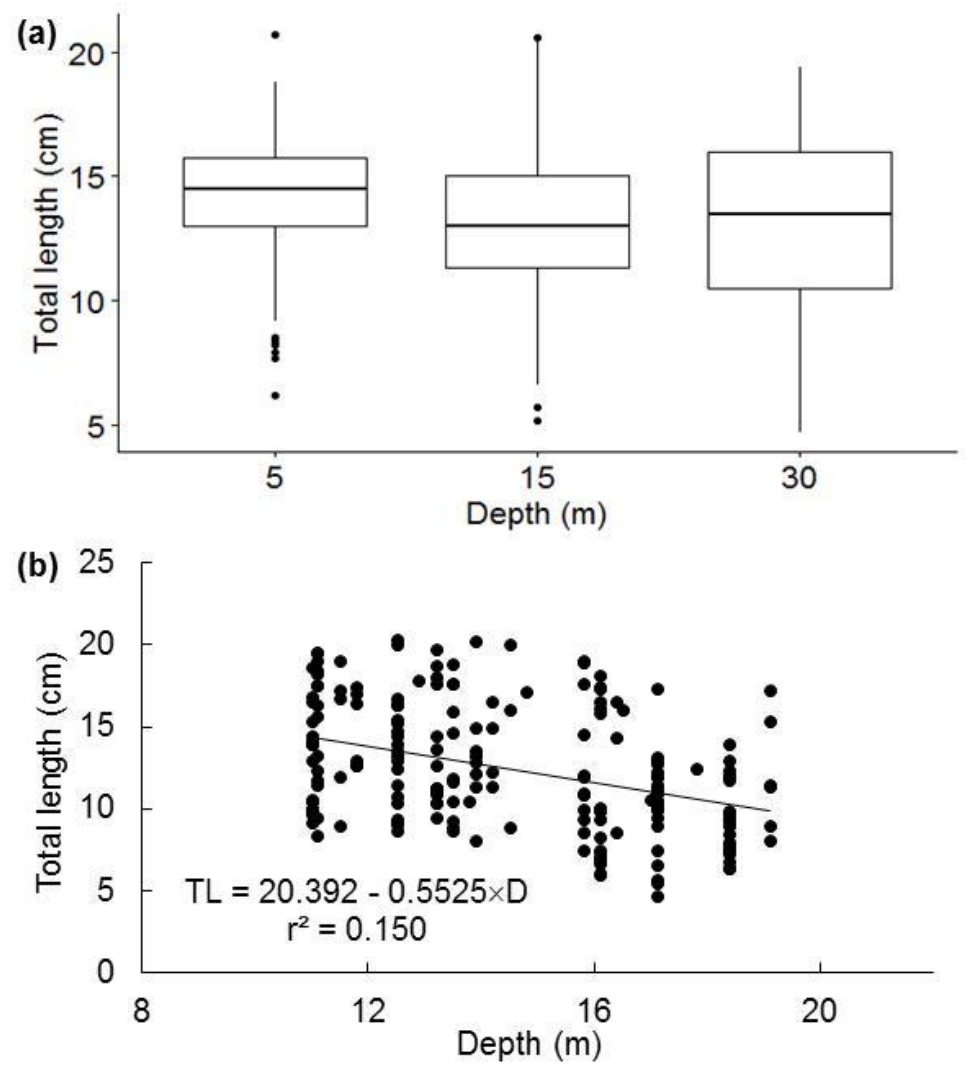

Figure 5: Total length (cm) of Paralonchurus brasiliensis in the coast of Sergipe in relation to depth $(\mathrm{m})$ : (a) Sampling program (1) (hired boat, codend mesh size=18 mm, 2013-2014), where horizontal line corresponds to median total length for each depth $(5,15$, and $30 \mathrm{~m})$, boxes to interquartile range, whiskers to minimum and maximum total length excluding outliers represented by black circles; $(b)$ Sampling program (3) (hired boat, codend mesh size $=20 \mathrm{~mm}, 2017-2018$ ), where each black circle corresponds to total length of each specimen sampled at a given local depth $(11-19 \mathrm{~m})$. 
The abundance of $P$. brasiliensis was higher at $15 \mathrm{~m}$ during most of the year (sampling program (1); Figure 6a). Data from the sampling program (3) was restricted to a depth range of 11-19 m, indicating that the highest number of individuals was observed at $11 \mathrm{~m}$ in February, and at $13 \mathrm{~m}$ and $17 \mathrm{~m}$ in October and May (Figure 6b). This depth range appeared to be insufficient to reflect any clear seasonal pattern. Conversely, Robert, Michels-Souza and Chaves (2007) [29] found higher abundance at smaller depth $(10 \mathrm{~m})$ along the coast of Paraná state, which reflects different features of the habitat in both regions. According to Santos (2010) [33], shrimp trawling occurs within the depth range of 2-30 m in northeastern Brazil. The sampling program (1) was broad enough to show a higher abundance of $P$. brasiliensis at $15 \mathrm{~m}$ for most of the year in Sergipe state, and larger individuals at $5 \mathrm{~m}$.
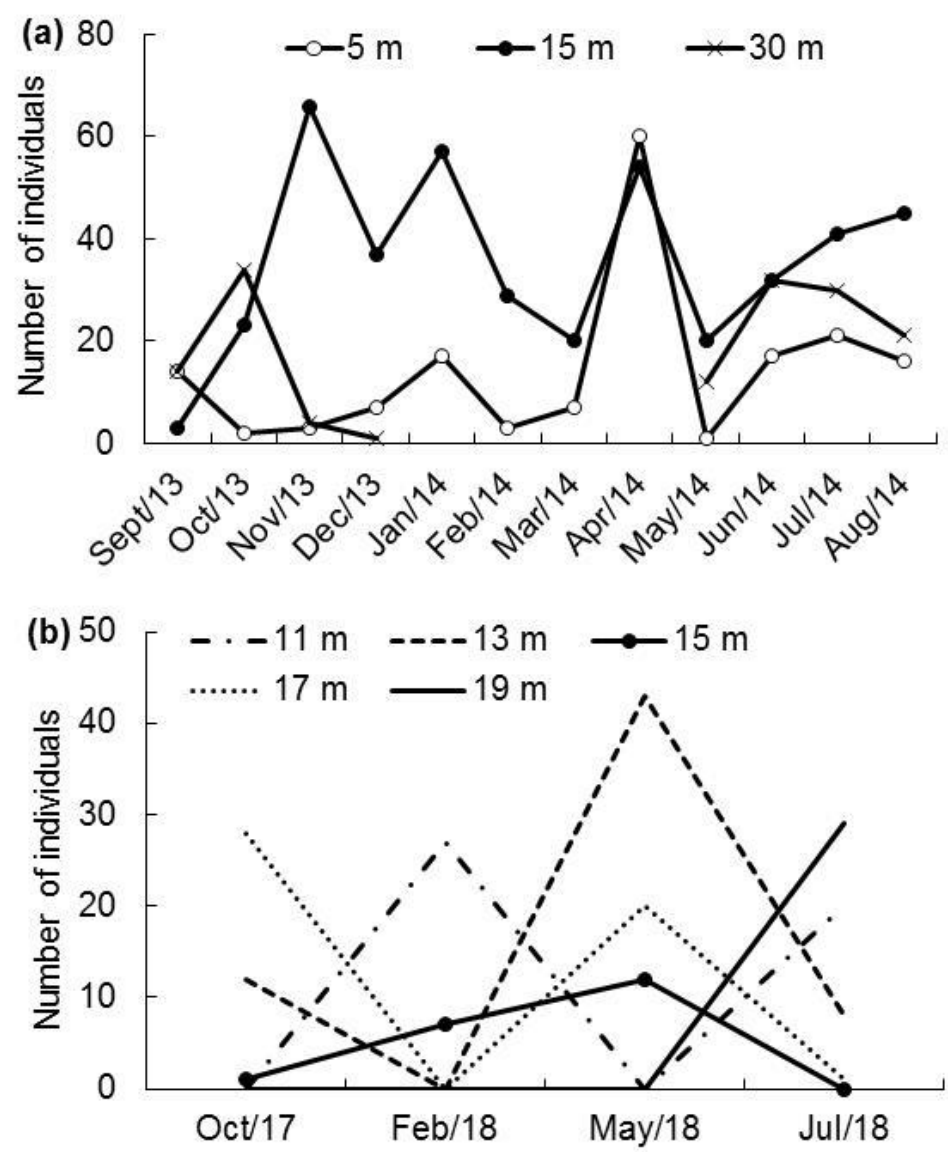

Figure 6: Number of individuals of Paralonchurus brasiliensis in relation to depth ( $m)$ and month/year from samples collected by two hired boats in the coast of Sergipe: (a) Sampling program 1 (2013-2014, mesh size=18 mm; (b) Sampling program 3 (2017-2018; mesh size=20 mm).

The weight-length relationship (WLR) estimated for $P$. brasiliensis indicated a positive allometry (b>3): TW $=0.00270 \times \mathrm{TL}^{3.391}$ (confidence interval for $\mathrm{b}=3.357-3.425$; confidence interval for $\left.\mathrm{a}=0.00248-0.00295 ; \mathrm{n}=1479 ; \mathrm{r}^{2}=0.963\right)$. This relationship was statistically significant $\left(\mathrm{F}=3.8 \times 10^{4} ; \mathrm{p}<0.0001\right)$. The value of $\mathrm{b}$ was within the usual range of $2.5-3.5$, as observed for most of the fish species [34]. The pair of $b$ and $\log a$ values estimated per month for each sampling program included in this study indicated this relationship changes seasonally, probably due to (i) different ontogenetic stages in the same period with distinct energetic demands, (ii) reproductive activity with large changes in the volume of gonads, and (iii) feeding behavior with increases in the allocation of fat channeled towards fulfilling energy requirements for reproduction, when ' $b$ ' values of the WLR may be higher than 3.5 (Table 2; Figure 7). Most of the values at the right end of this figure correspond to estimates from samples collected in February-March. Recruitment was mainly observed in September-October, which could correspond to individuals spawning from January to 
March. Thus, this period is most likely a reproduction peak in the coast of Sergipe state, if we consider the growth curves available in the literature $[16,28]$. All other WLRs estimated for this species available in FishBase [15] indicate very similar results within an almost perfect linear relationship $\left(\mathrm{r}^{2}=0.99\right.$; Figure 7$)$. The two extreme values (to the left and to right) correspond to the month of October, which again corresponds to the recruitment period. Thus, it seems that October is an important month to understand the population structure and dynamics of $P$. brasiliensis in Sergipe.

Table 2: Values of a and b for weight-length relationships (WLRs) estimated for Paralonchurus brasiliensis in the coast of Sergipe in four sampling programs: (1) hired boat, codend mesh size $=18 \mathrm{~mm}(2013-2014)$; (2) complete sample from commercial boat, codend mesh size=21 mm (2015-2016); (3) hired boat, codend mesh size=20 mm (2017-2018); (4) commercial boat, codend mesh size=20 mm (2018-2019; samples from 'miunça' and 'pescadinha'). $n=$ sample size; $r^{2}=$ coefficient of determination of WLRs estimated based on total length $(T L ; \mathrm{cm})$ and total weight $(T W ; \mathrm{g})$. Note that WLR was not reported for some months in sampling programs (2) and (4) due to closed seasons or reduced sample size.

\begin{tabular}{|c|c|c|c|c|c|c|c|}
\hline $\begin{array}{c}\text { Sampling } \\
\text { program }\end{array}$ & Month/Year & $\mathrm{n}$ & $\mathrm{a}$ & $\mathrm{b}$ & $r^{2}$ & $\begin{array}{c}\text { Lower } \\
\text { TL }\end{array}$ & $\begin{array}{c}\text { Upper } \\
\text { TL }\end{array}$ \\
\hline \multirow[t]{12}{*}{ (1) } & September/13 & 29 & 0.00275 & 3.361 & 0.982 & 5.7 & 17.0 \\
\hline & October/13 & 59 & 0.00400 & 3.316 & 0.908 & 4.7 & 18.8 \\
\hline & November/13 & 74 & 0.00448 & 3.197 & 0.931 & 9.1 & 17.6 \\
\hline & December/13 & 45 & 0.00260 & 3.419 & 0.969 & 10.0 & 18.1 \\
\hline & January/14 & 74 & 0.00186 & 3.525 & 0.884 & 6.6 & 17.0 \\
\hline & February/14 & 32 & 0.00177 & 3.509 & 0.778 & 8.0 & 17.2 \\
\hline & March/14 & 27 & 0.00364 & 3.305 & 0.894 & 13.0 & 16.7 \\
\hline & April/14 & 113 & 0.00116 & 3.693 & 0.913 & 9.3 & 20.7 \\
\hline & May/14 & 33 & 0.00235 & 3.461 & 0.990 & 5.0 & 18.6 \\
\hline & June/14 & 81 & 0.00174 & 3.555 & 0.979 & 8.3 & 20.4 \\
\hline & July/14 & 91 & 0.00271 & 3.394 & 0.956 & 8.2 & 20.6 \\
\hline & August/14 & 82 & 0.00276 & 3.344 & 0.941 & 7.6 & 18.0 \\
\hline \multirow[t]{8}{*}{ (2) } & May/15 & 10 & 0.00160 & 3.601 & 0.996 & 9.4 & 19.2 \\
\hline & July/15 & 33 & 0.00340 & 3.329 & 0.979 & 5.1 & 13.1 \\
\hline & August/15 & 60 & 0.00200 & 3.454 & 0.966 & 5.0 & 19.5 \\
\hline & September/15 & 159 & 0.00140 & 3.655 & 0.955 & 6.1 & 19.6 \\
\hline & October/15 & 11 & 0.00070 & 3.836 & 0.952 & 8.9 & 15.9 \\
\hline & November/15 & 102 & 0.00100 & 3.774 & 0.950 & 10.6 & 22.8 \\
\hline & February/16 & 15 & 0.00130 & 3.656 & 0.985 & 8.7 & 16.9 \\
\hline & March/16 & 18 & 0.00120 & 3.676 & 0.982 & 10.0 & 19.2 \\
\hline \multirow[t]{4}{*}{ (3) } & October/17 & 41 & 0.00920 & 2.917 & 0.899 & 4.7 & 18.8 \\
\hline & February/18 & 34 & 0.00140 & 3.644 & 0.988 & 8.9 & 20.0 \\
\hline & May/18 & 75 & 0.00500 & 3.182 & 0.965 & 6.0 & 20.3 \\
\hline & July/18 & 58 & 0.00430 & 3.236 & 0.975 & 6.4 & 20.2 \\
\hline \multirow[t]{4}{*}{ (4) } & October/18 & 29 & 0.00450 & 3.220 & 0.936 & 14.6 & 22.9 \\
\hline & February/19 & 39 & 0.00100 & 3.758 & 0.950 & 14.6 & 21.5 \\
\hline & March/19 & 18 & 0.00210 & 3.483 & 0.938 & 14.6 & 22.3 \\
\hline & July/19 & 17 & 0.00140 & 3.641 & 0.952 & 14.8 & 20.3 \\
\hline TOTAL & 2013-2019 & 1479 & 0.00270 & 3.391 & 0.963 & 4.7 & 22.9 \\
\hline
\end{tabular}




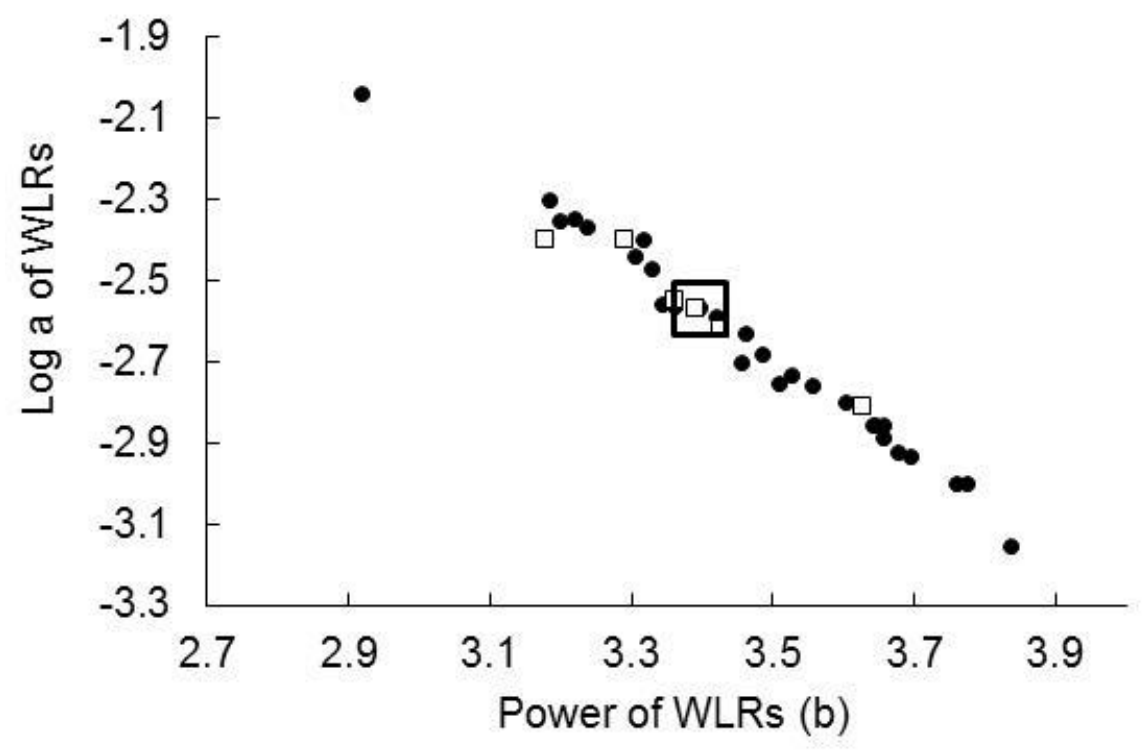

Figure 7: Parameters a and b of weight-length relationships (WRLs) estimated by month for Paralonchurus brasiliensis in all sampling programs (1-4) carried out along the coast of Sergipe (black circles) and for all samples together (large white square), as well as from other studies available in FishBase (small white squares) [34].

\section{CONCLUSION}

Paralonchurus brasiliensis is recognized as part of the bycatch of shrimp fisheries in Sergipe state, but to date it had never been reported in catch statistics. Here we demonstrated, for the first time, that this species is commercialized in the local market in Aracaju municipality under the categories known as 'miunça' and 'pescadinha'. Smaller individuals were included in the category 'miunça' in relation to 'pescadinha', but all of them were larger than $14.4 \mathrm{~cm}$ TL. However, individuals smaller than $14.4 \mathrm{~cm}$ TL were found in the region and caught by shrimp trawlers (all of them probably immature), which may have been discarded by commercial fishers, as they do not show up in the catch statistics (31-35\% of the total weight of P. brasiliensis, depending on the mesh size). Thus, the impact of fishing on stocks of this population may remain undetected if landings are not examined in detail. Moreover, the use of excluding devices and monitoring efforts could avoid excessive discards, while the remaining small specimens that are caught could be utilized for purposes that improve food security.

Recruitment most likely occurs mainly in September-October and May, which is possibly associated with reproduction peaks from January to March and from September to October, respectively. It is strongly recommended that reproduction studies are conducted in the region to test this hypothesis. A broader sampling program was able to show a higher abundance of $P$. brasiliensis at $15 \mathrm{~m}$ for most of the year in Sergipe state, with larger individuals observed at $5 \mathrm{~m}$. The growth is allometric positive with variation along the year. The low selectivity of the fishing gear used leads to the capture of a large number of juveniles, which may have a large impact in the dynamic population of this species as well as other species found in the same shrimp fishing ground. Catch statistics have to include greater detail in the identification of smaller fishes to better assess the percentage of juveniles of both target and non-target species.

\section{ACKNOWLEDGEMENTS}

We would like to thank IBAMA for the permission to sample and transport wild fauna for scientific purposes Proc\# no. 02070.001067/2013-96, according to the state and federal regulatory rules (SISBIO) and Conselho Nacional de Desenvolvimento Científico e Tecnológico (CNPq) for financial support (482802/2012-0) (Sampling program 1); Maria Moraes and fishers/skippers for the collection of samples for sampling program (2) in Pirambu; to Diógenes Lopes for facilitating 
the collection of samples for sampling program (4) in Aracaju; and to Dr. Patricia Keen for reviewing the English version of this manuscript. Sampling program (2) was partially supported by the Projeto de Monitoramento Participativo de Desembarque Pesqueiro (PMPDP) and the Fundação de Apoio à Pesquisa e Extensão de Sergipe (FAPESE) (Grant numbers 2600.0094374.14.4 and 2600.0099827.15.4). Sampling program (3) was partially financed by the Coordenação de Aperfeiçoamento de Pessoal de Nível Superior (CAPES) - Finance Code 001. MFGB received a CNPq research grant (306851/2018-0).

\section{REFERENCES}

1. FAO. The state of world fisheries and aquaculture 2018. Meeting the sustainable development goals. Rome: Food and Agriculture Organization; 2018. $210 \mathrm{p}$.

2. MPA. Boletim estatístico da pesca e aquicultura. Brasil 2011. Brasília: Ministério da Pesca e Aquicultura; 2012. $60 \mathrm{p}$.

3. Araújo ARR, Barbosa JM, Santos JP, Carvalho BLF, Garciov Filho EB, Deda MS, Silva CO, Chammas MA. Boletim estatístico da pesca nos litorais de Sergipe e extremo norte da Bahia - 2014. São Cristóvão: Editora UFS; 2016. $82 \mathrm{p}$.

4. Thomé-Souza MJF, Carvalho BLF, Garciov Filho EB, Silva CO, Deda MS, Félix DCF, Santos JC. Estatística pesqueira da costa do estado de Sergipe e extremo norte da Bahia 2013. São Cristóvão: Editora UFS; 2014. 108 p.

5. MMA. Instrução Normativa ${ }^{\circ} 14$, de 14 de outubro de 2004. Proibir, anualmente, o exercício da pesca de camarão rosa (Farfantepenaeus subtilis e Farfantepenaeus brasiliensis), camarão sete-barbas (Xiphopenaeus kroyeri) e camarão branco (Litopenaeus schmitti), com quaisquer artes de pesca, nas áreas e períodos abaixo discriminados. Available from: https://www.gov.br/agricultura/ptbr/assuntos/aquicultura-e-pesca/legislacao/arrasto/instrucao-normativa-mma-no-14-de-14-102004.pdf/view

6. Santos CR, Silva RLS, Costa CR, Davanso MT, Hirose LG. Evaluation of the management plan for penaeid shrimps in the continental shelf of Sergipe, Brazil. Bol Inst Pesca. 2017;43:308-21, doi: 10.20950/1678-2305.2017v43n3p308.

7. Branco JO, Verani JR. Pesca do camarão sete-barbas e sua fauna acompanhante, na Armação do Itapocoroy, Penha, SC. In: Branco JO, Marenzi AWC, editors. Bases ecológicas para um desenvolvimento sustentável: estudos de caso em Penha, SC; Itajaí (SC): Editora da Univali; 2006. p. 153-70.

8. Lazzari MA, Sherman S, Kanwit JK. Nursery use of shallow habitats by epibenthic fishes in Maine nearshore waters. Estuar Coast Shelf Sci. 2003 Jan;56:73-84, doi: 10.1016/S0272-7714(02)00122-1.

9. Branco JO, Fracasso HAA. Ocorrência e abundância da carcinofauna acompanhante na pesca do camarão sete-barbas, Xiphopenaeus kroyeri Heller (Crustacea, Decapoda), na Armação do Itapocoroy, Penha, Santa Catarina, Brasil. Rev Bras Zool. 2004 Jun;21(2):295-301, doi: 10.1590/S010181752004000200022

10. Braga MSC, Salles R, Fonteles-Filho AA. Ictiofauna acompanhante da pesca de camarões com rede-dearrasto na zona costeira do município de Fortaleza, estado do Ceará, Brasil. Arq Ciên Mar. 2001;34:4960, doi: 10.32360/acmar.v34i1-2.11652

11. Silva Júnior CAB, Viana AP, Frédou FL, Frédou T. Aspects of the reproductive biology and characterization of Sciaenidae captured as bycatch in the prawn trawling in the northeastern Brazil. Acta Sci Biol Sci. 2015 Jan-Mar;37(1):1-8, doi: 10.4025/actascibiolsci.v37i1.24962.

12. Silva Júnior CAB, Lira AS, Eduardo LN, Viana AP, Lucena-Frédou F, Frédou T. Ichthyofauna bycatch of the artisanal fishery of penaeid shrimps in Pernambuco, northeastern Brazil. Bol Inst Pesca. 2019;45(1):e435, doi: 10.20950/1678-2305.2019.45.1.435.

13. Barreto TMRR, Freire KMF, Reis-Júnior JJC, Rosa LC, Carvalho-Filho A, Rotundo MM. Fish species caught by shrimp trawlers off the coast of Sergipe, in north-eastern Brazil, and their length-weight relations. Acta Ichthyol Pisc. 2018;48(3):277-83, doi: 10.3750/AIEP/02334.

14. Fricke R, Eschmeyer WN, Laan Rvd. Eschmeyer's catalog of fishes: genera, species, references. 2020. Available from: http://researcharchive.calacademy.org/research/ichthyology/catalog/fishcatmain.asp [accessed 2020 Aug 4].

15. Froese R, Pauly D. FishBase. Version 12/2019. 2019. Available from: www.fishbase.org [accessed 2019 Mar].

16. Lewis DS, Fontoura NF. Maturity and growth of Paralonchurus brasiliensis females in southern Brazil (Teleostei, Perciformes, Sciaenidae). J Appl Ichthyol. 2005 Apr;21:94-100, doi: 10.1111/j.14390426.2004.00637.x. 
17. Menezes NA, Figueiredo JL. Manual de peixes marinhos do sudeste do Brasil. IV-Teleostei (3). São Paulo, Brazil: Museu de Zoologia, Universidade de São Paulo; 1980. 96 p.

18. Chao NL. Sciaenidae. Croakers (drums). In: Carpenter KE, editor. The living marine resources of the Western Central Atlantic. Volume 3: Bony fishes part 2 (Opistognathidae to Molidae), sea turtles and marine mammals. Roma: Food and Agriculture Organization of the United Nations; 2002. p. 1583-653.

19. Sedrez MC. Bioecologia de Paralonchurus brasiliensis (Steindachner, 1875) capturados na pesca artesanal de arrasto de Xiphopenaeus kroyeri (Heller, 1862), Penha, Santa Catarina, Brasil [PhD thesis]. São Carlos (SP): Universidade Federal de São Carlos; 2017. 127 p.

20. Alcântara AV, Siqueira KLF. Ictiofauna demersal da plataforma continental de Sergipe e Sul de Alagoas. In: Carneiro MER, Arguelho MLPM, editors. Plataforma continental de Sergipe e Alagoas: geoquímica e comunidade bêntica. São Cristóvão (SE): Editora Universidade Federal de Sergipe; 2018. p. 379-419.

21. Thomé-Souza MJF, Dantas Júnior JF, Silva FCB, Félix DCF, Santos JC. Estatística pesqueira da costa do Estado de Sergipe e Extremo norte da Bahia 2010. São Cristóvão: Editora UFS; 2012. 88 p.

22. Thomé-Souza MJF, Carvalho BLF, Silva CO, Deda MS, Garciov Filho EB, Félix DCF, Santos JC. Estatística pesqueira da costa do estado de Sergipe e extremo norte da Bahia 2012. São Cristóvão: Editora UFS; 2014. 102 p.

23. Thomé-Souza MJF, Deda MS, Santos JP, Carvalho BLF, Araújo MLG, Garciov Filho EB, Félix DCF, Santos JC. Estatística pesqueira da costa do estado de Sergipe e extremo norte da Bahia 2011. São Cristóvão: Editora UFS; 2013. 92 p.

24. Alcântara AV. A ictiofauna do estuário do Rio Sergipe. In: Alves JPH, editor. Rio Sergipe: importância, vulnerabilidade e preservação. Aracaju (SE): Ós Editora; 2006. p. 111-41.

25. Mair P, Wilcox R. Robust statistical methods in R using the WRS2 package. Behav. Res. 2020;52:46488, doi: https://doi.org/10.3758/s13428-019-01246-w.

26. R Core Team. R: A language and environment for statistical computing. R Foundation for Statistical Computing, Vienna, Austria. 2020. Available from: http://www.R-project.org/ [accessed May 2020].

27. Cook RD, Weisberg S. Residuals and influence in regression. New York: Chapman and Hall; 1982. 230 p.

28. Santos Costa EF, Freire FAM, Teixeira GM, Fransozo A. Growth and mortality parameters of Paralonchurus brasiliensis (Sciaenidae) captured as bycatch in Southeastern of Brazil. J Mar Biol Oceanogr. 2013;2:4, doi: 10.4172/2324-8661.1000120.

29. Robert MC, Michels-Souza MA, Chaves PT. Biologia de Paralonchurus brasiliensis (Steindachner) (Teleostei, Sciaenidae) no litoral sul do Estado do Paraná, Brasil. Rev Bras Zool. 2007 Mar;24(1):191-8, doi: 10.1590/S0101-81752007000100024

30. Bartolino V, Ciannelli L, Bacheler NM, Chan KS. Ontogenetic and sex-specific differences in densitydependent habitat selection of a marine fish population. Ecology. 2010 Dec;92(1):189-200, doi: 10.1890/09-1129.1.

31. Pittman SJ, McAlpine CA. Movements of marine fish and decapod crustaceans: process, theory and application. Adv Mar Biol. 2003 Jan;44(1):205-94, doi: 10.1016/S0065-2881(03)44004-2.

32. Fontes LCS, Santos JR, Santos LA, Oliveira-Júnior EA. Geologia da margem continental da bacia de Sergipe-Alagoas, NE do Brasil. In: Fontes LCS, Kowsmann RO, Puga-Bernabéu A, editors. Geologia e geomorfologia da bacia de Sergipe-Alagoas. São Cristóvão (SE): Editora UFS; 2017. p. 9-21.

33. Santos MCF. Ordenamento da pesca de camarões no nordeste do Brasil. Bol Téc Cient. CEPENE. 2010;18(1):91-8.

34. Froese R. Cube law, condition factor and weight-length relationships: history, meta-analysis and recommendations. J Appl Ichthyol. 2006 Aug;22(4):241-53, doi: 10.1111/j.1439-0426.2006.00805.x. 